Warszawa 2019

PFLIT, issue 9(12), part 1: 33-62

JAGODA WIERZEJSKA

Faculty of Polish Studies

University of Warsaw

\title{
A DOMESTIC SPACE: \\ THE CENTRAL AND EASTERN CARPATHIANS \\ IN THE POLISH TOURIST AND LOCAL LORE DISCOURSE, $1918-1939^{1}$
}

Keywords: domestic landscape, national landscape, regionalism, mass tourism, Carpathians Słowa kluczowe: krajobraz rodzimy, krajobraz narodowy, regionalizm, turystyka masowa, Karpaty

\section{Su m m a ry}

The article presents various ways of ideologization of the Central (Boyko and Lemko regions) and Eastern (Hutsul region) Carpathians in interwar Poland. After the Polish-Ukrainian War (1918-1919), that part of the Carpathian mountain range was situated in the Second Polish Republic. In contrast to the Tatras, which played the role of Polish national landscape, the Carpathians were alien to Poles in terms of ethnicity and culture. Thus, the Polish authorities, as well as touristic and local lore organizations, sought and largely managed to transform these mountains into a domestic landscape, which was no center of national identity but constituted an important spot on the mental map of the Polish national community, recognized as an undeniable part of Polish statehood. The article shows how the exoticization of the Carpathians, state holidays, and the development of state-funded mass tourism resulted in the increased sense of familiarity between Polish lowlanders and highlanders and, consequently, the symbolic inscription of the Carpathians into the Polish domain and common imagination.

\section{KRAJOBRAZ RODZIMY. ŚRODKOWE I WSCHODNIE KARPATY W POLSKIM DYSKURSIE TURYSTYCZNYM I KRAJOZNAWCZYM LAT 1918-1939}

\section{Streszczenie}

Artykuł prezentuje różne sposoby ideologizacji przestrzeni Karpat Wschodnich (Huculszczyzny) i Środkowych (Bojkowszczyzny i Łemkowszczyzny) w międzywojennej Polsce. Po wojnie polsko-ukraińskiej (1918-1919) ta część łańcucha Karpackiego znalazła się w II Rzeczpospolitej. W odróżnieniu od Tatr, które odgrywały rolę krajobrazu narodowego dla Polaków, stanowiła

${ }^{1}$ The article is an effect of the research project 2017/01/X/HS2/01152 financed by the National Center of Science (Poland). 
jednak ziemię pod względem etnicznym i kulturowym obcą Polakom, co więcej, podatną na wpływy ukraińskiego ruchu narodowego. Polskie władze oraz organizacje krajoznawcze i turystyczne dokładały w związku z tym dużo starań, aby przekształcić Karpaty w krajobraz rodzimy, czyli przestrzeń, która wprawdzie nie była ośrodkiem identyfikacji narodowej Polaków, ale była im bliska i wpisywała się w ich wyobrażenie Polski jako integralnej całości. Wykład pokazuje, w jaki sposób egzotycyzacja Karpat, państwowe święta i imprezy, w końcu finansowany przez II RP rozwój masowej turystyki prowadziły do budowania poczucia swojskości między Polakami z nizin a góralami, a w konsekwencji - do symbolicznego wpisania Karpat w domenę polską i zbiorową wyobraźnię Polaków.

\section{Introduction}

The Carpathians constitute the largest mountain range in East-Central Europe. Nowadays, they run through territories of eight countries, from Austria and the Czech Republic in the northwest through Slovakia, Poland, Hungary, and Ukraine to Romania and Serbia in the southeast. Historically, the Carpathians had a typical borderland character. In the sixteenth century, their large stretch demarcated the border between the Crown of Hungary and the Polish-Lithuanian Commonwealth (after the Union of Lublin in 1569). In the wake of the partitions of the latter, in the last third of the eighteenth century, the Carpathians found itself in the Habsburg Empire. After the Austrian-Hungarian compromise of 1867, the Carpathians was an internal frontier of the Dual Monarchy, marking the border between Austria and Hungary; or, precisely speaking, the Austrian province of Galicia. As a consequence of the collapse of the Monarchy (1918) and the Polish-Ukrainian War (1918-1919), the former Galicia was included into the Second Polish Republic along with approximately six hundred kilometers of the Carpathians, from the Silesian Beskids to Chornohora. In the interwar period, that part of the mountains walled off the predominantly lowland Poland to the south and separated it from Czechoslovakia and Romania; after the Munich Agreement also from Hungary.

Despite the borderland and immensely peripheral character of the Carpathians, they started to attract representatives of different nations already in the late nineteenth century. The beauty of their wild alpine nature lured an increasing number of travelers, discoverers, and artists. Furthermore, the complexity of their ethnic composition provided offered work for intelligentsia engaged in nation-building projects. In this article, I will argue that, although the Low Beskids, Bieszczady, Gorgany, and Chornohora were never landscapes of particular importance for the national identification of Poles, the interwar Polish elites appropriated these mountains to Polish nation and state in hope of transforming them into a Polish "domestic landscape." 
Although inhabitants of the Carpathians were generally known as highlanders, they were divided into disparate ethnic groups. For instance, those dwelling in the northern part of the Tatras were called Gorals; those inhabiting the Low Beskids, Bieszczady, and the mountain ranges located within the basin of the Prut and Cheremosh Rivers - Gorgany and Chornohora - were referred to as Lemkos, Boykos, and Hutsuls, respectively. Their complex ethnic origins are a subject of dispute until now, especially when it comes to the last three groups. ${ }^{2}$ Their origins were additionally complicated by the mixing of people. The identity of highlanders in the second half of the nineteenth century was typically local, that is, tied to the specific alpine terrain that over the centuries had shaped their way of living. However, the "discovery" of the Carpathians at that time changed the situation and raised the national question with respect to the vernacular population. The aforementioned "discovery" is a term elaborated by Patrice M. Dabrowski that captures the process of inscribing the Carpathians into the mental map of people and associating them with nation-building in the region and, then, among the broad national masses. ${ }^{3}$ According to Dabrowski, the first phenomenon of this kind occurred in the 1870s and referred to the Tatra Mountains, then located in the Habsburg Galicia. Doctor Tytus Chałubiński and the Polish positivists instilled interest in the Tatras and established the first region's alpine association, the Polish Tatra Society (Polskie Towarzystwo Tatrzańskie; 1873), while the preoccupation of Polish elites with the Zakopane style helped Polish nationalists to recognize the Tatras as a national Polish territory and the Gorals as undeniably Polish people. ${ }^{4}$ Moreover, the "discovery" of the Tatras strengthened the Polish identification of the Gorals themselves.

Such an appropriation of the Tatras and their inhabitants for the Polish nation was followed by the "discovery" of the Eastern Carpathians known as the Hutsul

${ }^{2}$ There are many theories concerning the ethnogeny of the Lemkos, Boykos, and Hutsuls. Perhaps, the one with the most supporters that argues that they originate from Vlachs. However, alternative conceptions appeared, even quite recently. E.g., in the 1970s Tadeusz Sulimirski sought to prove that the Lemkos and Boykos have Thracian origins, vide Tadeusz Sulimirski, "Trakowie w Północnych Karpatach i problem pochodzenia Wołochów," Acta Archeologica Carpathica, vol. 14 (1974): 79-105. Paul R. Magocsi fosters a conception on existence of the Carpatho-Rusyn nation which is to embrace the Lemkos, Boykos, and Hutsuls, vide Paul R. Magocsi, Shaping of a National Identity: Subcarpathian Rus', 1848-1948 (Harvard: Harvard University Press, 1978), and his The People From Nowhere: An Illustrated History of Carpatho-Rusyns (Uzhorod: V. Padiak Publishers, 2006).

${ }^{3}$ Patrice M. Dabrowski, “'Discovering' the Borderlands: The Case of the Eastern Carpathians," Slavic Review, vol. 64, no. 2 (2005): 380-381.

${ }^{4}$ Patrice M. Dabrowski, "Constructing a Polish Landscape: The Example of the Carpathian Frontier," Austrian History Yearbook, vol. 39 (2008): 45-65; David Crowley, "Finding Poland in the Margins: The Case of the Zakopane Style,” Journal of Design History, vol. 14, no. 2 (2001): 105-116. 
region. Unlike the Tatras, this part of Galicia turned out to be a field of battle for influence between Poles and Ukrainians. The Poles established new branches of the Tatra Society in Eastern Galician towns, Stanisławów and Kołomyja, and took advantage of the first ethnographic exhibition in Kołomyja in $1880^{5}$ to emphasize the Polish spirit and leadership in the Hutsul region. However, Dabrowski claims that they did not elevate the Hutsuls to the position of full-fledged members of the Polish nation, as they did with the Gorals. ${ }^{6}$ At the beginning of the twentieth century, Ukrainian intelligentsia started to manifest a growing interest in the Eastern Carpathians, took inspiration from the Hutsul culture, and appeared more eager than the Poles to perceive the vernacular highlanders as a regional variant of their nation. Hereby, already in the period preceding the First World War, the Hutsul region and its dwellers became a bone of contention between Poland and Ukraine, both stateless and aspiring to represent and control this remote piece of the Habsburg lands as far as possible.

The First World War and, in particular, the Polish-Ukrainian War for Eastern Galicia opened a new chapter in the history of the formerly Habsburg part of the Carpathians. On the one hand, the Polish-Ukrainian war proved that Ukrainians laid rigid state-building claims toward the area that they regarded as their ethnic territory, including not only the Hutsul and Boyko regions but also the Lemko region situated west of the San River. ${ }^{7}$ On the other hand, the Polish victory in the war, sealed by the Peace of Riga (1921) and the international recognition of the Polish sovereignty in Eastern Galicia (1923), entailed the incorporation of the whole province, along with its highlands and highlanders, into reborn Poland.

While the position of the Tatras on the mental map of Poles was clear at that time, the mountains already gained an honorable status of that what Alexander Maxwell calls a "national landscape," that is, a center of national identification; ${ }^{8}$ thus, the position of the Central and Eastern Carpathians was ambiguous. The Low Beskids, Bieszczady, Gorgany, and Chornohora were regarded by Poles as part of a territorial heritage of the Polish-Lithuanian Commonwealth; a part that, after the epoch of partitions, should belong to the Second Polish Republic. However, in contrast to the Tatras, Poles hardly perceived these mountain ranges as their "national landscapes." Especially for the Poles from the former

\footnotetext{
${ }^{5}$ Patrice M. Dabrowski, “'Discovering' the Borderlands:” 385-402.

${ }^{6}$ Ibidem: 401.

${ }^{7}$ Vide Maciej Kozłowski, Między Sanem a Zbruczem. Walki o Lwów i Galicję Wschodnia 1918-1919 (Kraków: Wydawnictwo Znak, 1990), 110-111.

${ }^{8}$ Vide Alexander Maxwell, "From Wild Carpathians to the Puszta: The Evolution of Hungarian National Landscapes," in Mythical Landscapes Then and Now: The Mystification of Landscapes in Search for National Identity, eds. Ruth Büttner, Judith Peltz (Yerevan: Antares, 2006), $53-77$.
} 
Russian and Prussian partitions, the Carpathians were remote; they were also much less discovered (and "discovered") then the Tatras. Moreover, the highlanders from the Central and Eastern Carpathians - the Lemkos, Boykos, and Hutsuls - considerably varied from Roman Catholic Poles. Roman Reinfuss, a Polish ethnographer, called them generally "Rusyn highlanders" ("górale ruscy"). ${ }^{9}$ Reinfuss did not define the notion and he certainly did not anticipate the contemporary category of Carpatho-Rusyns proposed by Robert P. Magocsi and Paul Best as a separate nation. ${ }^{10}$ However, "Rusyn highlanders" did reflect Reinfuss's sense of difference between the Poles and the Central and Eastern highlanders who were Eastern Slavs of Greek Catholic or Orthodox rite and close linguistic kinship with the Ukrainians.

As I mentioned, the Ukrainians tend to consider the Lemkos, Boykos, and Hutsuls as a part of the Ukrainian nation, so they continued nation-building among the highlanders after 1918 even though the authorities of the Second Polish Republic did much to suppress their attempts. On their part, and if politically active, the highlanders sympathized with miscellaneous orientations: the Ukrainians, the Moscophils, the Old Rus, and the pro-Polish regime. ${ }^{11}$ However, the highlanders generally seemed scarcely bound to the idea of the region's Polishness and the more east of the Carpathians they dwelled, the more susceptible they were to Ukrainian influence. That complex situation made the issue of the highlanders' national allegiance and the precarious links between the Carpathian borderland and the rest of the Polish state into the burning problems of interwar Poland.

The article concerns the most problematic stretch of the Carpathians located within the borders of the Second Polish Republic, that is, the Low Beskids, Bieszczady, Gorgany, and Chornohora. The paper discusses the means used by the interwar Polish elites to connect these mountains with the lowland area of Poland and the ethnic minorities of Lemkos, Boykos, and Hutsuls with the Polish nation. I will focus on the interwar Polish discourse pertaining to the Central and Eastern Carpathians and the thematic fields of tourism and history

${ }^{9}$ Roman Reinfuss, "Łemkowie (opis etnograficzny)," Wierchy, vol. 14 (1936): 1.

${ }^{10}$ Vide Paul R. Magocsi, Shaping of a National Identity; The People From Nowhere; Paul J. Best, "The Carpatho-Rusyn Question in Poland," in The Lemkos of Poland, eds. Paul J. Best, Jarosław Moklak (Kraków-New Haven: Carpatho-Slavic Studies Group, 2000), 73-81.

${ }^{11}$ Jarosław Moklak, "Political Orientations Among the Lemkos in the Interwar Period (1918-1939): An Outline," in The Lemkos of Poland, 27-32; Jarosław Moklak, The Lemko Region in the Second Polish Republic: Political and Interdenominational Issues 1918-1939, trans. Timothy Williams (Kraków: Jagiellonian University Press, 2013), 11-119. 
in the context of the local community. Moreover, I will analyze popular guidebooks of the time that presented the region and made it the subject of public discussion between the First and Second World Wars: Karpaty i Podkarpacie (The Carpathians and the Subcarpathia; 1939) devoted to the Low Beskids and Bieszczady, as well as Huculszczyzna. Gorgany i Czarnohora (The Hutsul Region. Gorgany and Chornohora; 1936), both written by the Polish writer and explorer Ferdynand Antoni Ossendowski and issued in the famous publishing series "Cuda Polski" (The Wonders of Poland). ${ }^{12}$ Moreover, I consider the successful, in its time, guidebook Krótki przewodnik po Huculszczyźnie (A Short Guidebook of the Hutsul Region; 1933). Moreover, my investigation follows the monthly Turysta $w$ Polsce (Tourist in Poland) jointly issued in 1935-1938 by the Tatra Society, the Polish Skiing Association (Polski Związek Narciarstwa) and the Polish Kayaking Association (Polski Związek Kajakarstwa), as well as selected articles from the yearbook Wierchy (Mountain Peaks), published by the Tatra Society since 1923 . What comprises a supplementary field of my reflection are iconographical sources like the album Województwo stanistawowskie $i$ tarnopolskie (Stanisławów and Tarnopol Voivodeship; 1930), included in the publishing project "Polska w krajobrazie i zabytkach" ("Poland: its landscape and monuments"), ${ }^{13}$ and 1929-1938 photographs of the Lemko and Boyko regions by Reinfuss. On the basis of these materials, I will indicate the main threads of the Polish tourist and local lore discourse on the Central and Eastern Carpathians in 1918-1939: (1) exoticization; (2) regional distinctiveness; (3) past and current connections with Poland; (4) "touristification" as the connection to the Second Polish Republic. I will argue that, although the Low Beskids, Bieszczady, Gorgany, and Chornohora never played an equal role as the Tatras who were the "national landscape" for Poles, the interwar Polish elites sought and largely managed to transform these mountains into a "domestic landscape." Domestic landscape is not a center of national identity; yet, despite its local otherness, it constitutes an important spot on the mental map of a national community that recognizes it as an undeniable part of its statehood. Due to the systematic and consistent coverage of the Central and Eastern Carpathians with special meanings applied by creators of the Polish tourist and local lore discourse in the Second Polish Republic, the Carpathians mostly became such a landscape before 1939 .

${ }^{12}$ Based on French models, the series appeared in 1928-1939. Each of the fourteen volumes presented a different part of the Second Polish Republic, with special consideration of its geography, history, and culture.

${ }^{13}$ The series consisted of fourteen short volumes compiled into two monumental books, the first was published in 1930, the second in 1931. Volumes were dedicated to a different region or city of the interwar Poland, gathering a few short articles but mostly beautiful photographs. 


\section{The Exoticization of the Localism}

The alpine landscape, boasting an abundance of wildlife, was a feature of the Central and Eastern Carpathians emphasized by virtually all travelers, discoverers, and artists who visited the region. The south-eastern part of the Second Polish Republic, that is, Gorgany and Chornohora, were regarded by Poles as the wildest and most remote. Consequently, the wildness and seclusion of these mountain ranges became their hallmarks in the Polish tourist and local lore discourse.

Articles devoted to Gorgany, less known and popular than Chornohora in the 1920s and 1930s, usually began with depictions of the mountains' hardly accessible forests, cliffs, and endless stone run. For instance, a journalist of the monthly Turysta $w$ Polsce ensures his readers and possible visitors to Gorgany that:

You will be impressed by the lush green of giant stone pine clusters and the dark, impenetrable, sea of mugo pine, frozen into a unified green. Higher, there are only stone islands of rocks, i.e. stone run [gorgan].... Only thence, tens of kilometers of the wondrous landscape, the endless mountain lands, open like a fan. ${ }^{14}$

Another journalist, summing up the monthly's texts that promote the Carpathians among Polish lowlanders, admits that, "the 'alpine terrain of the Tatras,' the 'gorgeous Bieszczady, specifically for skiing,' the 'wild Chornohora,' we know them by heart from all the publications and propagandist articles." 15 This journalist aptly captures the tendency to attribute wildness to Gorgany and Chornohora. However, what he does not add is that the tendency manifested itself not only in journalism but also in different, semiotically-understood cultural texts.

In modeling the perspective on the south-eastern corner of Poland as extraordinary wilderness, the interwar Polish photography played at least as important role as journalism. The monthly Turysta $w$ Polsce used this means to affect the awareness and imagination of its readers, who often lacked personal experience in the mountains. Apart from articles, the monthly published many photos of usually good artistic quality, by popular tourist activists and travelers, among others, Mieczysław Orłowicz, Zygmunt Klemensiewicz, and Maksymilian Dudryk. Their works displayed Gorgany and Chornohora in a similar way, most often as an unbroken view of hills and rocks stretching to the horizon, scarcely populated, and distant from the areas spoiled by modern civilization. The album Województwo stanistawowskie i tarnopolskie depicted the mountains analogously. According to the title of the series in which it appeared, the album presents images of monuments and works of art located in towns and villages of Stanisławów and Tarnopol Voivodeship along with photographs of the landscape,

\footnotetext{
${ }^{14}$ Władysław Krygowski, “Gorgany - góry czaru,” Turysta w Polsce, no. 7 (1936): 8.

15 "Góry polskie - kraj narciarzy," Turysta w Polsce, no. 12 (1937): 12.
} 
that is, the Gorgany and Chornohora mountain ranges. Amid the latter group, there dominate monumental panoramas from mountaintops and romantic shots of secluded locations in the valleys of the Prut and Cheremosh Rivers. These images suggest that visitors may find there peace, quiet, and the most authentic nature, as well as a sense of adventure in the mountains. ${ }^{16}$ Popular postcards from the interwar period followed this way of presentation. For instance, one of them shows a pair of skis and poles stuck in fresh snow on the backdrop of the Homul peak in winter Chornohora. ${ }^{17}$ The whole composition emanates tranquility and a seductive promise of escape from the city crowd and everyday life, a place of solitude, excitement, and a bit of hazardous experience. Some shots of Gorgany and Chornohora were so often reproduced that they became highly recognizable. The especially popular views were the winter peaks of Małe Kozły and Wielkie Kozły, ${ }^{18}$ as well as the famous Chornohora rugged rocks called the "stone theatres" by Henryk Gąsiorowski, the author of guidebooks of the Eastern Beskids. ${ }^{19}$

Guidebooks, publications that combine narrative and photography, made a significant contribution to the establishment of the analyzed image of the Carpathians. The guidebook Huculszczyzna provides a telling testimony to this phenomenon. Its author, Ossendowski, was clearly captivated by the beauty of the Hutsul region and very eager to present it to readers as a wonder of nature. Not only did Ossendowski describe Gorgany and Chornohora as a region full of rare species of plants and animals but also - or especially - as a marvelous wilderness that offers visitors the freedom and possibility of unique adventures. Admiring the Eastern Carpathians' hunting conditions, "so appealing to the imagination of the hunter," Ossendowski boldly compares the Carpathians to Central Africa and India and states that the indigenous mountains surpass

${ }^{16}$ Vide e.g. the photographs by Henryk Gąsiorowski, J. Jaroszyński, and Stanisław Radomski in Województwo stanistawowskie i tarnopolskie (Rzeszów: Libra PL, 2012), 28-39. I use the contemporary reprint of the edition Województwo stanistawowskie i tarnopolskie (Warszawa: Wydawnictwo Tadeusza Złotnickiego, 1930), having compared it with the original version from the National Library in Warsaw (Poland). While the reprint is supplemented by additional materials, the item in the National Library is incomplete and lacks the introductory articles by Gąsiorowski and Tomasz Kunzek.

${ }^{17}$ Ibidem, 31.

${ }^{18}$ Vide e.g. the photograph by Zenobiusz Pręgowski in Andrzej Wielocha, Przedwojenne Bieszczady, Gorgany i Czarnohora. Najpiękniejsze fotografie (Warszawa: Wydawnictwo RM, 2013), 82.

${ }^{19}$ Henryk Gąsiorowski, Przewodnik po Beskidach Wschodnich, vol. 1, part 1: Bieszczady (Warszawa: Książnica-Atlas, 1935); idem, Przewodnik po Beskidach Wschodnich, vol. 1, part 2: Gorgany (Warszawa: Książnica-Atlas, 1935); Henryk Gąsiorowski, Przewodnik po Beskidach Wschodnich, vol. 2: Czarnohora (Warszawa: Książnica-Atlas, [1933]). According to Gąsiorowski, the "stone theatres" was a popular folk name of Szpyci, "the most beautiful detail of Chornohora," Henryk Gąsiorowski, Przewodnik po Beskidach Wschodnich, vol. 2: Czarnohora, 109. 
the overseas areas with regard to the quality of air, water, and forests, not to mention the number of wild animals. ${ }^{20}$ Ossendowski's parallel suggests something less than an orientalization of Gorgany and Chornohora and more like an exoticization of the beautifully natural wild mountains. Simultaneously, his description brings about an evident appreciation of the region's localism. According to Ossendowski, the chains in south-eastern Poland are not only withstand comparison to the non-European lands but also successfully draw tourists away from those lands to the terrain that is domestic but not less original and exotic.

The notion of exoticization of the mountains' localism allows us to describe the general trend in presenting Gorgany and Chornohora, less frequently Bieszczady and the Low Beskids, in the Polish tourist and local lore discourse. Although the manifestation of this trend was very distinct in the form of Ossendowski's parallel between the south-eastern Polish borderland and the exotic lands, the trend in question did not have to involve such an open juxtaposition. Instead, it consisted in emphasizing attractiveness, originality, and sometimes even oddity of the mountains which, though domestic, did not give way to more distant and supposedly more alluring tourist destinations.

We find many various displays of this trend in the discourse of the time. Apart from the above, the guidebook by Ossendowski provides many others. For example, it depicts the Hutsul region as a captivating place, which "involuntarily births the thought about a fairy tale hidden there." 21 According to the writer, the Hutsuls live close to nature, at the crossroad of Christianity and fascinating "Slavic and non-Slavic paganism;" 22 thus, their culture and the region itself are penetrated by magic. Ossendowski apparently enjoyed describing Hutsuls' magical practices (especially those connected with love, fertility, and death) and supernatural forces allegedly active in the mountains.

[witchcraft has nested here [in the Hutsul region] from time immemorial. In slits and fissures of Szpyci [a peak in Chornohora], there grow miraculous medicinal herbs, magic flowers, and fairy roots, and they receive power from "he" - the black spirit of the mountains who wonders in this grim and menacing place. ${ }^{23}$

This is only a sample of a broad picture but very representative of Ossendowski's book, which was to portray Gorgany and Chornohora as an amazing and deeply mysterious region. Stories about local heroic outlaws that appear on the pages of Huculszczyzna and Karpaty i Podkarpacie aim at the same representation.

${ }^{20}$ Antoni F. Ossendowski, Huculszczyzna. Gorgany i Czarnohora (Poznań: Wydawnictwo Polskie R. Wegner, [1936]), 24-25.

${ }^{21}$ Ibidem, 197.

${ }^{22}$ Ibidem, 165.

${ }^{23}$ Ibidem, 155. 
They suggest that the Carpathians are full of unusual people who deserve appreciation, even if they act against the law or morality, because they contribute to the good of the local people. What especially played such role was the legend of Ołeksa Dobosz, vivid amid the Hutsuls and appropriated by Polish culture in Eugeniusz Brocki's novel "Opryszki w Karpatach" (Robbers in the Carpathians; 1830). ${ }^{24}$ Ossendowski depicts Dobosz as a robber like Robin Hood, who "melted plundered gold into joy, ... understood the language of forests, the howl of wind, and the thud of storm [hodyna] on the uplands, and drank the charm of life." ${ }^{25}$ In this way, Ossendowski attributes the Hutsul hero Dobosz with such characteristics as the love of liberty and inner connection with nature and the archaic past, which Poles previously assigned mostly to the Tatra Gorals. Since Ossendowski treats the protagonist as the best synecdoche of the Hutsul population, he tacitly extends Dobosz's features of character to all vernacular highlanders: "[Dobosz was the] embodiment of all songs [dumy] and affections of the people." Consequently, the readers could have received the Hutsuls much like the Gorals, who were regarded by Poles not only as undeniably Polish but also as the most attractive and appealing ethnic group who dwells on the Polish lands.

All these manners of exoticization of the Central and, especially, Eastern Carpathians had a persuasive function. By elevating the localism of Carpathians to the level of extraordinary attraction and creating the image of the mountains as a magic kingdom of nature and archaic past, the writers strongly appealed to sensibility and imagination of Poles unfamiliar with the region. Hence, they persuaded Polish lowlanders that the south-eastern borderland of the Second Polish Republic deserved attention and visit regardless of two facts. First, that the Carpathians were a periphery of Poland and not an appealing foreign territory. Second, that this periphery was hardly accessible and far away from such centers as the capital of the state, Warsaw. ${ }^{27}$ The analyzed image of the Central and Eastern Carpathians offered a tempting vision of retreat, adventure and real exoticism in the domestic space. In this way, as Krótki przewodnik po Huculszczyźnie puts it, the texts were to "encourage tourists, skiers, holiday-makers, and amateurs of beautiful nature to explore this nook of the [Polish] Republic, by all means worth knowing." 28

${ }^{24}$ Eugeniusz Brocki, “Opryszki w Karpatach. Powieść z podań gminnych,” Hałyczanin, ed. Walenty Chłędowski, Lwów, vol. 2 (1830): 78-92.

${ }^{25}$ Antoni F. Ossendowski, Huculszczyzna, 135.

${ }^{26}$ Ibidem.

${ }^{27}$ Turysta $w$ Polsce informed that, in the late 1930s, it took "only" twelve hours to get by train from Warsaw to Sławsko, the tourist center in Eastern Bieszczady, Jim Poker, "Cepry i turystyka," Turysta w Polsce, no. 4-5 (1938): 10.

${ }^{28}$ Krótki przewodnik po Huculszczyźnie od Hnitesy po Rogoze, ed. komitet redakcyjny (Warszawa: Główna Księgarnia Wojskowa, 1933), n.p. 


\section{The Janus Face of Regionalism}

Local and ethnic peculiarity of the Central and Eastern Carpathians and their dwellers constituted a highly valued property of the region, which the interwar tourist and local lore Polish discourse constantly reiterated. The authors of the album Województwo stanistawowskie i tarnopolskie devoted much space to display the Hutsul culture and customs, even though the volume focused on monuments and landscape of the Stanisławów and Tarnopol Voivodship, not ethnography. The album conveys pictures of a wedding in the center of the Hutsul region (Żabie), divinations after wedding, a Hutsul funeral, fishing in the Cheremosh River, trembita players, laundry in Kosów, and several Hutsul types, from children to old men and women, mostly by Mikołaj Seńkowski. ${ }^{29}$

The outstanding ethnographer, Reinfuss, dedicated the vast majority of his interwar travel and research projects to recording and analyzing the world of the Central and Eastern Carpathian highlanders. He immortalized life in the area between the Poprad and Cheremosh Rivers - the Lemkos region, the transition Lemko-Boyko terrain, the Boyko region, and the Boyko-Hutsul borderland - on photographs taken in the late 1920s and 1930s. ${ }^{30}$ Moreover, Reinfuss commented on the disputed issues concerning the area of his interest (e.g. the borderline of the Lemko region) in articles, until 1936 published in the newspaper Ilustrowany Kurier Codzienny (Illustrated Daily Courier), ${ }^{31}$ later in reputable journals about ethnography, local lore, and local history. ${ }^{32}$

In his both guidebooks, Ossendowski devotes many pages to describe the life patterns of pastoral people who live in the territory from the Low Beskids to Chornohora. Trained in and most famous for literary memoires, ${ }^{33}$ Ossendowski embellished his local lore narrative with short stories about specific characters that familiarized readers with the Lemko, Boyko, and Hutsul mentality and lifestyle.

${ }^{29}$ Vide the photographs by Mikołaj Seńkowski and Henryk Gąsiorowski in Województwo stanistawowskie i tarnopolskie, 41-64.

${ }^{30}$ Photographs by Reinfuss are to be found in the archive of the Rural Architecture Museum of Sanok. His selected works are presented in Roman Reinfuss, Fotografie. Karpacki świat Bojków $i$ Łemków, eds. Zbigniew Libera, Hubert Ossadnik (Olszanica: Wydawnictwo Bosz and Muzeum Budownictwa Ludowego w Sanoku, 2016).

${ }^{31}$ E.g., Roman Reinfuss, "W sprawie granicy łemkowsko-boykowskiej," Kurier Literacko-Naukowy, no. 7, appendix to Ilustrowany Kurier Codzienny, no. 48 (17 February 1936): xiv-xv; Roman Reinfuss, “Wschodnia granica Lemkowszczyzny,” Kurier Literacko-Naukowy, no. 28, appendix to Ilustrowany Kurier Codzienny, no. 193 (13 July 1936): ix-x.

${ }^{32}$ E.g., Roman Reinfuss, "Etnograficzne granice Łemkowszczyzny,” Ziemia, vol. 26, no. 10/11 (1936): 240-254; Roman Reinfuss, "Łemkowie:” 1-24; Roman Reinfuss, "Ze studiów nad kulturą materialną Bojków," Rocznik Ziem Górskich (Warszawa: Zakłady Drukarskie W. Piekarniaka, 1939): 238-279.

${ }^{33}$ Vide Antoni F. Ossendowski, Beasts, Men and Gods (New York: E. P. Dutton \& Company, 1922). 
In the guidebook Karpaty $i$ Podkarpacie, there is a story about an old Lemko shepherd, Atanas, who at the dusk of life reminisces on his experiences, all connected with the unforgiving but sublime Low Beskids. ${ }^{34}$ In Huculszczyzna, there is a story that depicts the funeral of an old farmer ( $g a z d a)$ in Żabie. ${ }^{35}$ Ossendowski highly appreciates authentic manifestations of the local culture and customs - even unsophisticated - which is how he perceives the Lemko art. He wishes that the regional distinctiveness had not been contaminated with external influences and writes with a sense of regret about the "historical necessity" for civilization to encroach upon the uplands. ${ }^{36}$ However, in the light of our reflections in the present article, we clearly see that these wishes and regrets did not deter Ossendowski from attracting visitors and paying special attention to the issue of tourism development in the Carpathians.

According to Ossendowski, ${ }^{37}$ a "serious organization" with a statutory objective to maintain the local specifics of the Eastern Carpathians was the Society of Friends of the Hutsul Region (Towarzystwo Przyjaciół Huculszczyzny) founded in 1933. Its charter promulgated that the Society aimed at (1) cooperation in the methodical economic and cultural development of the region, (2) protection of the region's properties that comprised its distinctiveness and constitutes a "valuable component in the sum of natural and spiritual resources of the Polish Republic," (3) utilization of the climatic values of the region to improve the "social hygiene of the State," (4) supervision of the methodical development of tourism, summer resorts, and health spas in the region. ${ }^{38}$ At first glance, the Society seems a typical local lore institution in the type of an alpine club. However, the rhetoric of its charter and its activities (to which I will return) were marked by a sort of antinomy, which one could already detect in Ossendowski's thinking. On the one hand, the Society was devoted to preserving the culture of the Eastern Carpathian highlanders and improving their territory. On the other hand, it emphasizes the special role of the south-eastern periphery - a "valuable component ... of the Polish Republic" - for Poland. The Society sought increasing the active presence of Poles in the area; therefore, it strengthened links between the Hutsul region and the rest of the Polish state. Officially, the Society was a non-governmental institution. However, the fact that it was headed by general Tadeusz Kasprzycki, a high official in the Ministry of Military Affairs and, in 1935-1939, the Minister of Military Affairs, linked it to the political circle

${ }^{34}$ Antoni F. Ossendowski, Karpaty i Podkarpacie (Poznań: Wydawnictwo Polskie R. Wegnera, [1939]), 64-73.

${ }^{35}$ Antoni F. Ossendowski, Huculszczyzna, 109-120.

${ }^{36}$ Antoni F. Ossendowski, Karpaty i Podkarpacie, 62.

${ }^{37}$ Antoni F. Ossendowski, Huculszczyzna, 145.

${ }^{38}$ Statut Towarzystwa Przyjaciót Huculszczyzny (Warszawa: Towarzystwo Przyjaciół Huculszczyzny, 1934), 4. 
in power after Józef Piłsudski's May 1926 coup d'état. The financial and organizational support that the Society received from the Polish authorities and army made it a "serious organization" with influence exceeding the Carpathians.

As the Society's charter suggested, preserving the highlanders' culture was at least as important in interwar Poland as promoting it amid the lowlanders. In the 1930s, the Society organized several events to meet both of these aims. One of the most important was the Mountain Holiday (Święto Gór), planned already in 1933 and eventually organized in August 1935 in Zakopane. For five days, groups of highlanders from throughout the Polish Carpathians - from the Silesian Beskids to Chornohora - displayed their cultural and artistic achievements, partaking in disparate competitions, especially folk song and dance. Walery Goetel, a Polish geologist, longtime editor-in-chief of the yearbook Wierchy, and author writing for the monthly Turysta $w$ Polsce, defines the main goal of those performances as follows: "they give an impulse to maintain and develop the most valuable characteristics of the highland tribes of Poland and their cooperation." ${ }^{39}$ Indeed, the folk competition form of the Mountain Holiday elevated regional traditions to the rank of high value and encouraged highlanders to cultivate their cultural heritage. However, the organizational frameworks and Goetel's supplementary comments reveal additional goals of the Mountain Holiday. The event was organized by the Tatra Society, the Society of Friends of the Hutsul Region, and the Association of Highlanders (Związek Podhalan) under the leadership of Kasprzycki and honorable patronage of the President of Poland, Ignacy Mościcki, and Marshal Piłsudski, with considerable support from the Polish army. The touristic dimension of the Mountain Holiday was as essential as the local lore one. Goetel expresses satisfaction with the fact that it turned out to be a great touristic success: "Tens of thousands of people arrived at Zakopane by tens of special trains." ${ }^{40}$ What was particularly meaningful for the scholar was that the vast majority of those people constituted lowlanders, unfamiliar with the mountains, who yet immediately realize in Zakopane that "the life of contemporary Poland received enrichment from a new, invaluable element." "Hence," Goetel concludes elsewhere, "the great propagandistic and social importance of the rally." ${ }^{2}$ The great importance of the Mountain Holiday consisted in the popularization of the southern and south-eastern borderlands among the Poles from other parts of the Second Polish Republic and the development of their awareness of the borderlands as an integral part of the country. Not less important was another goal of the event: affecting the awareness

\footnotetext{
${ }^{39}$ Walery Goetel, "Święto Gór," Turysta w Polsce, no. 7 (1935): 7.

${ }^{40}$ Ibidem.

${ }^{41}$ Walery Goetel, “Zagadnienia regionalizmu górskiego w Polsce,” Wierchy, vol. 16 (1938): 132.

${ }^{42}$ Walery Goetel, "Święto Gór:" 7.
} 
of the highlanders. Common performances during one huge Mountain Holiday "reinforced a sense of community of all Polish highland tribes," ${ }^{43}$ states Goetel. Moreover, vivid public interest in the event, presence of the state authorities, including the President, and funding from Polish organizations encouraged the highlanders to regard themselves as full-fledged and valuable citizens of the Second Polish Republic. Fostering the highlanders' sense of brotherhood and belonging to Poland was crucial for the organizers, which found a telling testimony in the following facts. Originally, a highland group that would win folk competitions was supposed to win a free trip around Poland. However, all highlander participants in the Holiday were eventually sent for such a trip so as to have the possibility to recognize their homeland as more than only private and regional. ${ }^{44}$ Moreover, the leaders of regional groups along with tourist and local lore activists jointly decided to establish an organization that would work for "the unification and elevation - ideological, cultural, and economic - of all highland terrains of Poland." 45

Ultimately, the organization was initiated as the Union of Highland Terrains (Związek Ziem Górskich) during the Highland Congress in Sanok, August 15-17, 1936, and started its proceedings in Warsaw, in November of the same year. ${ }^{46}$ The Union comprised tourist and local lore organizations who dealt with mountain issues along with some state institutions like the Chamber of Commerce and Industry (Izba Przemysłowo-Handlowa). Activists of the Union underlined its engagement in the co-organization of works of lower level units and the preservation of regional specifics of the southern and south-eastern parts of Poland. However, the ideological goals of the Union went further. Goetel probably declares them most aptly, when during a discussion in Sanok, he explains that the organization should seek to "connect the Carpathians with the rest of Poland economically and culturally." 47

The objectives of the next Mountain Holiday in Wisła, August 1937, seemed convergent with the goals of the Union, which obviously was involved in its organization. For Goetel, the Mountain Holiday again was "revue of the original culture of highland people for thousands of their compatriots from lowlands,

${ }^{43}$ Ibidem.

${ }^{44}$ Ibidem.

${ }^{45}$ Ibidem.

${ }^{46}$ Walery Goetel, "Zjazd Górski w Sanoku i Związek Ziem Górskich,” Turysta w Polsce, no. 8 (1936): 2; Walery Goetel, "Góry polskie skarbnicą regionalizmu," Turysta w Polsce, no. 8 (1937): 8; Walery Goetel, "Zjazd Górski w Sanoku," Wierchy, vol. 14 (1936): 232-233; w. mil., "Powstanie Związku Ziem Górskich,” ibidem: 233.

${ }^{47}$ Quoted after Patrice M. Dabrowski, "Borderland Encounters in the Carpathian Mountains and Their Impact on Identity Formation," in Shatterzone of Empires Coexistence and Violence in the German, Habsburg, Russian, and Ottoman Borderlands, eds. Omer Bartov and Eric D. Weitz (Bloomington-Indianapolis: Indiana University Press, 2013), 203. 
which occurs in an appropriate staffage of the upland world." 48 Among others, it means that participants of the event, like two years ago, included the highlanders form the whole mountain territory of Poland. An abundance of attractions made the program very entertaining and drew even more visitors to Wisła than the previous Mountain Holiday to Zakopane. The organizers sought to instill in the highlanders' an awareness that their culture constituted a highlight for the newcomers. On the other hand, the organizers did a lot to arouse lowlanders' interest in the culture of the highlanders and to get the former group closer to the latter. Not only did the organizers arrange lectures about the mountains and trips to the most beautiful viewpoints but they also put a funfair in Wisła ${ }^{49}$ similar to the amusement popular in bigger towns and cities in lowland Poland. One can say that the organizers indeed endeavored to create "compatriots" - as Goetel suggested it - or, as contemporary scholars call it, a sense of belonging to the same "imagined community," ${ }^{50}$ shared by the highlanders and lowlanders alike. Commentators of the event willingly expanded that sense of community into different spheres of life, especially social and economic ones. For instance, Kazimierz Pawlewski in the article "After the 'Mountain Week' in Wisła" states that the Holiday paved way for the development of highlanders' welfare "in accordance with the common interest of Poland.... The uplands must become, at all costs, not only a wall of breasts of brave and sacrificial highland people but also a wall of economic prosperity of the state." ${ }^{51}$

Such projects as the Society of Friends of the Hutsul Region, the Union of Highlands, and the Holidays of Mountains along with the approach represented by Ossendowski, Goetel, and Pawlewski, agreed with the ideology of regionalism as understood in interwar Poland. While the geographer Stanisław Pawłowski generally states that regionalism is a trend aiming at "examining objects and phenomena on the earth, according to their native regions," ${ }^{, 52}$ Goetel develops his thought with regard to the mountains. The latter writes that "geographical and natural circumstances create the common basis of life" in the Carpathians, ${ }^{53}$ even though "their local characteristics vary distinctively." 54 Simultaneously, Goetel emphasizes the state dimension of regionalism, that is, the fact that

${ }^{48}$ Walery Goetel, “Zjazd górski w Sanoku i Związek Ziem Górskich:” 2.

${ }^{49}$ Vide the program of the event: “"Tydzień Gór' w Wiśle,” Turysta w Polsce, no. 8 (1937): 2-3.

${ }^{50}$ Vide Benedict Anderson, Imagined Communities: Reflections on the Origin and Spread of Nationalism (London: Verso, 1991 [revised and extended ed.; first ed. 1983]).

${ }^{51}$ Kazimierz Pawlewski, "Po 'Tygodniu Gór' w Wiśle," Turysta w Polsce, no. 9 (1937): 2.

${ }^{52}$ Stanisław Pawłowski, "Regionalizm geograficzny i jego rozwój w Polsce," in Ruch regionalistyczny w Europie, vol. 2, ed. Aleksander Patkowski (Warszawa: Sekcja Regjonalistyczno-Krajoznawcza Związku Nauczycielstwa Polskiego, 1934): 3.

${ }^{53}$ Walery Goetel, “Zagadnienia regionalizmu górskiego w Polsce:” 133.

${ }^{54}$ Ibidem: 140. 
"mountain matters must be subordinated to the matters of the country as a whole, which lies in the well-understood interest of the mountain area." 55 To that end, Goetel lists the "slogans" of regionalisms:

Treating the issue of the Carpathians as a great mountain unit of particular importance for our lowland motherland [of Poland]; combating separatism and provincialism while simultaneously cultivating regional distinctiveness ... showing an appropriate way of improvement of life to the local people; in this way, realizing the idea of unity in diversity; delivering values of the mountain lands and mountain people to Poland for the sake of interest of the Carpathian area and the whole State. ${ }^{56}$

Goetel's enumeration lets us infer that the ideology of "unity in diversity" had a Janus-faced nature. The ideology in question insisted on maintaining regional otherness as long as it remained secondary to the idea of the centralized Polish state. In fact, the slogan "unity in diversity" meant connecting the mountain province with the lowland heart of the Second Polish Republic and simultaneously subjecting the former to the latter. While the analyzed manifestations of tourist and local lore discourse constituted the particular means to achieve this goal, the general means can be defined in the following way. First, persuading lowlanders that the mountain province was an inherent part of their homeland, that is, the placement of the region's position on their mental maps. Second, turning the highlanders into loyal Polish citizens while keeping or even increasing their local and ethnic individuality. Both of these means were important and effective, but the latter was especially crucial and complex with respect to the Lemkos, Boykos, and Hutsuls.

As I mentioned, these highlanders not only differed from Poles in denomination and language but also constituted an easy target for Ukrainian activists' nation-building efforts in the Central and Eastern Carpathians. To counterbalance Ukrainian influences, the Polish state and intellectual elites did their best to show that cultural and economic development of the region was fueled by the Polish, not Ukrainian power. Moreover, they tried to persuade the Polish society and the highlanders that the latter benefited from and appreciated the Polish endeavor. For instance, Goetel convinces the readers of Wierchy that - after the 1935 Mountain Holiday - the leaders of Silesian, Lemko, Boyko, and Hutsul groups unanimously expressed their "gratitude to the [Polish] government and army for the protection of the mountain area." ${ }^{" 57}$ In turn, Ossendowski argues that an intensive influx of tourists and bathers to the Low Beskids would raise it out of poverty and "bond this frantically, artificially, obtrusively Ukrainized Lemko region

\footnotetext{
${ }^{55}$ Ibidem: 149.

${ }^{56}$ Ibidem: 164.

${ }^{57}$ Ibidem: 165.
} 
to Poland." ${ }^{58}$ According to Ossendowski, only if such bonds were strengthened could the Lemko culture survive under the aegis of the Second Polish Republic, which would enhance the Lemko's devotion to the state even more. Otherwise, the highlanders who "penetrated by disparate social theories" - as Ossendowski periphrastically calls Ukrainian nation-building - would "forget archaic customs and even turn away from the Greek Orthodox Church." ${ }^{59}$ Obviously, Ossendowski's argumentation is marked by contradiction. There was no reason why links with Poland were to preserve the Lemko legacy while those with Ukraine - the existing Soviet one or the imagined united one - were to destroy it. Regardless of this fact, Ossendowski's statement reveals that merging the Central and Eastern Carpathians with the Second Polish Republic primarily entailed the bringing of the Lemkos, Boykos, and Hutsuls - with all their cultural diversity - closer to the predominantly Polish society. Apart from building lowlanders' relationship with the highlands, what constituted an indispensable aspect of that process was the appreciation of the highlanders' uniqueness. Since establishing the national Polish identity of the dwellers of the Central and Eastern Carpathians seemed precarious, such appreciation could establish their civic Polish identity and contribute to their assimilation with the state - instead of the nation - as postulated by Marshal Piłsudski after the 1926 coup d'état. ${ }^{60}$ Consequently, this might deter the Lemkos, Boykos, and Hutsuls from becoming nationally-conscious Ukrainians, and perhaps motivate them to join the opposition to Polish regime.

\section{The Framework of Polishness}

Bringing closer the highlanders and lowlanders - not to mention fostering state assimilation of the Lemkos, Boykos, and Hutsuls - can be regarded as Polish state-building projects in the mountain periphery. Such manifestations of state-oriented regionalism as the Mountain Holidays constituted soft state-building projects. However, other threads of the tourist and local lore discourse emerged over time in interwar Poland. They emerged from the exacerbation

${ }^{58}$ Antoni F. Ossendowski, Karpaty i Podkarpacie, 63. Ossendowski does not elaborate the issue of Ukrainization of the Lemko region in a way that would explain his rigid adverbs. However, Ukrainian intelligentsia indeed intensified their nation-building there. The Prosvita society, which spread Ukrainian culture and education, was very active in the Low Beskids. Prosvita issued the newspaper Nasz Łemko (Our Lemko), which initially had had the title Ukrajinskyj Łemko (Ukrainian Lemko). In 1933, the Lemko Committee (Komisja Łemkowska) was established; it aimed at developing full national awareness of the Lemkos. Vide Jarosław Moklak, The Lemko Region in the Second Polish Republic, 102-117.

${ }^{59}$ Antoni F. Ossendowski, Karpaty $i$ Podkarpacie, 101.

${ }^{60}$ Czesław Madajczyk, "Dokumenty w sprawie polityki narodowościowej władz polskich po przewrocie majowym,” Dzieje Najnowsze, no. 3 (1972): 138. 
of Polish politics toward national minorities in the mid-1930s. Already in March 1934 the Committee for Nationality Matters (Komitet do Spraw Narodowościowych) was established at the Presidium of the Council of Ministers of the Second Polish Republic. In the course of the following two years, they created organizational structures that served the exacerbated minority politics. The Prime Minister, Marian Zyndram-Kościałkowski, promulgated the principles of minority politics at the beginning of 1936, that is, after the death of Marshal Piłsudski, when rigid political tendencies became conspicuous. According to Kościałkowski, minority politics should seek to reinforce the inner coherence of Poland by combining state and national assimilation of minorities. The new threads of the tourist and local lore discourse agreed with these processes and phenomena. In general, these threads constituted state-building projects of harder character than those analyzed above. With respect to the Central and Eastern Carpathians, they consisted in three discursive fields: underscoring putative old Polish tradition of the mountains, inscribing the mountains into Polish history, and connecting them with Polish contemporaneity.

In their work to underscore Polish tradition, the interwar guidebooks provided an expanded, if not comprehensive, outline of the history of the region, hence offering the largest range of analytical material. The guidebook Karpaty $i$ Podkarpacie by Ossendowski is particularly rich in this regard. Ossendowski willingly presents the Carpathians located within the Polish borders - regardless of whether Western, Central, or Eastern ones - as one consistent chain of mountain ranges deeply and evenly imbued with Polish heritage.

Ruins of castles stretch out from Cracow to Sniatyn, while the everlasting mainstays of Polishness, Subcarpathian towns, are united in the form of a powerful chain, ... and in old churches there are yellowed, rotten graves of Carpathian sons who frightfully defended the frontiers and matters of the motherland.... All this land and its people are penetrated and fulfilled by Polishness, our [Polish] culture, our thought, and the idea of the state that directs the whole life of the nation. ${ }^{61}$

As the quotation suggests, Ossendowski perceived Polish presence in the Carpathians as persistent and dating back to very old days. This way of his thinking is particularly pronounced with respect to the Low Beskids. In Ossendowski's opinion, the Lemko region was seriously threatened by "tumultuous propaganda," which presented it as “'genuinely Ruthenian territory,' in which we [Poles] were the "subsequent newcomers." 62 This is why he repeatedly advocated for Polish antecedence in the area predating the settlement of "Ruthenianized Vlachs" ("zruszczeni Kucowołosi"), ${ }^{63}$ as he called the predecessors of the Lemkos.

\footnotetext{
${ }^{61}$ Antoni F. Ossendowski, Karpaty i Podkarpacie, 22-25.

${ }^{62}$ Ibidem, 52.

${ }^{63}$ Ibidem.
} 
If the region was now predominantly inhabited by the Lemkos, it was because - Ossendowski assumes - the native Poles adjusted to them or resettled to different areas of Poland. ${ }^{64}$ The theory of the originally Polish settlement in the Low Beskids found no scientific proof. Instead, it brought to mind a similarly dubious conception popular in interwar Poland, but not acknowledged by ethnographers, about the Polish origins of the Lemkos. ${ }^{65}$ Regardless of that state of affairs, Ossendowski drew the following conclusion from his assumptions about the Lemko region: "This is our, eternal, ancient Polish [land], and it will remain Polish." ${ }^{66}$ Although when writing about the Eastern Carpathians, Ossendowski is more cautious than when writing about the Lemko region, he does indulge in describing a "Polish element" ${ }^{67}$ in the Boyko and Hutsul territory as well. He identifies this "element" with the Boykos and Hutsuls who allegedly have Polish lineage (e.g., a "Hutsul-Pole of Sarmatian countenance," 68 mentioned in Huculszczyzna) and, in particular, with minor gentry who dwells in the mountains. According to Ossendowski, the latter is imbued with "old Polish tradition ... that links it ... with the motherland," even though it was partly Ruthenianized and much akin to local peasantry. Ossendowski's apology of the minor gentry was grandiloquent: he did not refrain from such exclamations as "The Poles, you are the salt of this earth and its only rulers!" ${ }^{69}$ However, his local lore narrative tacitly reflects an action of "activization" of the minor gentry, that is Polonization, run in the Central and Eastern Carpathians by the Polish authorities and army since $1930 .{ }^{70}$ Moreover, Ossendowski focuses on great Polish nobles who held estates in the Subcarpathia, supposedly spread Polishness in the region as and raised it from cultural and economic backwardness. Fostering such a national perspective among this social group, he imbues the local nobles' power with a sense of Polish civilizing mission. Ossendowski claims

${ }^{64}$ Ibidem, 51-59, 69, 99-101.

${ }^{65}$ Vide Łemkowie - zapomniani Polacy. Województwo krakowskie, Łemkowszczyzna zachodnia: materiaty onomastyczne, ed. Aleksander Bartoszuk (Warszawa: Sekcja Naukowa Komitetu do Spraw Szlachty Zagrodowej na Wschodzie Polski, 1939).

${ }^{66}$ Antoni F. Ossendowski, Karpaty i Podkarpacie, 48.

${ }^{67}$ Ibidem, 183.

${ }^{68}$ Antoni F. Ossendowski, Huculszczyzna, 44.

${ }^{69}$ Antoni F. Ossendowski, Karpaty i Podkarpacie, 183.

${ }^{70}$ Vide propagandistic materials pertaining to the action: Roman Horoszkiewicz, Szlachta zaściankowa na ziemiach wschodnich (Warszawa-Pińsk: Polskie Towarzystwo Turystyczno-Krajoznawcze. Oddział Piński, 1936); Władysław Pulnarowicz, Rycerstwo polskie Podkarpacia (dawne dzieje i obecne obowiązki szlachty zagrodowej na Podkarpaciu) (Przemyśl: "Pobudki," 1937); Stanisław Jastrzębski, Kim jesteśmy? O szlachcie zagrodowej w Małopolsce Wschodniej (Przemyśl: "Pobudki," 1939). For further investigation of the issue vide Waldemar Paruch, "Mniejszości narodowe w myśli politycznej obozu piłsudczykowskiego (1935-1939)," in Polityka narodowościowa państw Europy Środkowowschodniej, eds. Jacek Ziemowit Pietraś, Andrzej Czarnocki (Lublin: IEŚ-W, 1993), 99-100. 
that the "civilizing" dimension of the nobles' authority was so valuable that it even warranted abuse of their subjects. However, he does not actually mention that the matter is controversial for Polish and Ukrainian historians who discussed it since the 1830s. The former simultaneously argued for the belonging of Eastern Galicia to the territory of the Polish nation. ${ }^{71}$

The inscribing of the Central and Eastern Carpathians into Polish history found its most telling manifestation in the main annual event of the Hutsul region, the three-day cross-country ski competition known as the March along the Hutsul Route of the Second Legionnaire Brigade. The first March was organized on February 16-18, 1934. At that time, the route led from the village Rajfałowa to Worochta, a famous spa resort. Two years later, it was extended so as to include other villages - Słoboda, Ranguska, Kosmacz, and Żabie - in order to intensify their tourist traffic. Indeed, the March had a great potential: it was rightly called by commentators the biggest sport event in the Eastern Carpathians, which annually drew to the region "a few thousand people." 72 However, it was also the biggest state event in the mountains. The circle of organizers of the March comprised not only tourist and local lore institutions - the Society of Friends of the Hutsul Region and the Polish Ski Association - but also the Polish army; the aforementioned official of the Ministry of Military Affairs, Kasprzycki, was its initiator while Marshal Piłsudski was its patron sponsor of the awards in his honor. According to the information brochure about the event, ${ }^{73}$ the March had two goals. The first was to commemorate the achievements of the Second Legionnaire Brigade that consisted of forces that fought with Russian ranks in the Eastern Carpathians in the winter of 1914/1915. The organizers tried very hard to underline the "historical coloring"74 of the competition, that is, to foreground a correspondence between it and the past deeds of the Polish soldiers. The event occurred at the heart of the Hutsul region, in February, because the Second Brigade was especially famous for its wintertime fights in this area. The March had a team-building character - skiers competed in groups, not individually - as the soldiers did to survive in extremely hard conditions. The March also included many military elements like participation of a military team with former Legionnaires and a shooting competition. Hence, the March actualized Legionnaire legacy - highly appreciated in interwar Poland, especially in Piłsudski circle - and shortly turned into a well-established tradition.

${ }^{71}$ Vide Burkhard Wöller, “Misja 'cywilizacyjna' czy ‘okupacyjna'? Aneksja Rusi Czerwonej w czasach Kazimierza III w kolonialistycznym dyskursie polskich i rusińskich historyków w habsburskiej Galicji," Historyka, vol. 42 (2012), 133-145.

${ }^{72}$ Az, “Marsz Szlakiem II Brygady Legionów,” Turysta w Polsce, no. 1-2 (1936): 6.

${ }^{73}$ Huculskim szlakiem II Brygady Legjonów Polskich (Warszawa: Wyd. Tow. Przyjaciół Huculszczyzny, 1934).

${ }^{74}$ Ibidem, 8. 
The second goal was to strengthen the relationship between the Hutsul region and the rest of Poland in the image of the past relationship between the Hutsuls and the Legionnaires during the First World War. This objective was probably even more important than the first one. This is why the civilian team who partook in the competition always included Hutsul representatives. This is also why so many publications that accompanied the March, from guidebooks to propagandistic articles, sought to spread the knowledge about a "beautiful tradition of military cooperation" between Polish soldiers and the Hutsul population. ${ }^{75}$ Indeed, some Hutsuls fought in Polish ranks, including the Second Brigade. Interwar Poles were very eager to interpret that fact as evidence of all Hutsuls' engagement in the fight for Polish independence. They neglected other facts, that some Hutsuls joined Ukrainian units of Sich Riflemen and that the majority of Hutsuls in Polish and Ukrainian forces most probably fought for Emperor Franz Joseph I, not for the independence of a Polish or Ukrainian state. The persistence of the above interpretation ensued from the fact that cooperation of some Hutsuls with the Legionnaires during the First World War constituted a convenient narrative to connect the inhabitants of the Eastern Carpathians with the matter of great importance for Poles. Due to this interpretation, the Hutsuls entered the most heroic page of Poland's history en masse: the rebirth of the Polish state. In turn, this narrative enabled Poles to clearly distinguishing the Hutsuls from Ukrainians, presenting the Hutsuls as Polish citizens loyal to the Poles from the lowlands and indeed persuading the Hutsuls that they were such citizens. The playful competition that gathered the highlanders and lowlanders along with the Polish authorities and army was a promising means to impose the Polish national perspective on the Hutsuls. The finish line of the March was decorated with Polish national colors and was the place in which all competitors ultimately met - military personnel and civilians, including Hutsuls - which constituted a meaningful symbol of the reactivation of the alleged Polish-Hutsul partnership of the recent past.

The connecting of the mountains with Polish contemporaneity was confirmed by the creation of the Main Carpathian Trail, today known as the Main Beskid Trail. As its first name suggests, this long-distance trail ran through all the Carpathians of interwar Poland. The western route, designed by the Polish geographer Kazimierz Sosnowski, was finished in 1929 and joined two spa resorts, Ustron and Krynica. The eastern route was built according to the project by Mieczysław Orłowicz, a lawyer, local lore activist, and the head of the Tourism

${ }^{75}$ Ibidem. Vide also Az, "Marsz Szlakiem II Brygady Legionów;" "Marsz Narciarski Huculskim Szlakiem Drugiej Brygady," Turysta w Polsce, no. 3 (1936); Władysław Krygowski, "Gorgany - góry czaru:" 8; Star., "Wśród gorgańskich szczytów i dolin,” Turysta w Polsce, no. 8 (1937): 7; Walery Goetel, "Zagadnienia regionalizmu górskiego w Polsce:” 133; Antoni F. Ossendowski, Huculszczyzna, 20, 29-38, 86; Krótki przewodnik po Huculszczyźnie, 41-44. 
Department of the Ministry of Communication. The easter route was finished in 1935 and led eastward to Żabie in Chornohora. A journalist who wrote for the monthly Turysta $w$ Polsce, in the first half of 1936, considered the newly created part of the Trail one of the most important tourist undertakings of the previous year. ${ }^{76}$ However, its significance did not confine to the field of tourism, which seemed clear for the vast majority of the Polish society, including the journalist. The Trail met the need for the unification of the Polish Carpathians, whose Western, Central, and Eastern parts were to be equally well studied, developed, and tethered to the Second Polish Republic. It was particularly relevant for the Lemko, Boyko, and Hutsul regions, less consolidated with Poland than the Western Carpathians. Therefore, when its eastern part was completed, the Trail openly started to combine the function of tourist facility and a symbol of Polish rule over the Carpathians, especially Central and Eastern. In 1935, the Trail was named "the mountain trail of Marshal Józef Piłsudski," which was intended as an "homage paid to the memory of the Great Man and the first protector of physical culture in Poland." 77 Additionally, on the day of Piłsudski's funeral on May 18, 1935, there were big candles lit on the main peaks along the Trail. ${ }^{78}$ Such gestures - anything but ideologically neutral - literally left an imprint of Polish power in the landscape of the mountains and, symbolically, emphasized its belonging to the domain of the Second Polish Republic. The fact found a telling expression in another article by the same journalist who appreciates the accomplishment of the eastern part of the Trail, "the Main Carpathian Trail - sanctified by the name of Piłsudski, every Pole's dearest - bonded the Polish mountains from Cieszyn to Żabie with the white-red color." "79 Indeed, connecting the mountain borderland with the current political context of the country made the Polish flag, "the white-red color," fully extend over the Central and Eastern Carpathians.

Underscoring Polish heritage of the mountains, inscribing them into Polish history, and connecting them with Polish contemporaneity constituted separate interpretative devices which all applied a distinctive meaning to the mountains. The first device, commonly used in guidebooks, confirms the thesis of David Lowenthal that "the past is a foreign country," 80 as it based on a recreation of representations of the past so that they suited the political interest of the Second Polish Republic. The second device, manifested itself in the March as an

${ }^{76}$ Władysław Krygowski, "Polskie Towarzystwo Tatrzańskie w roku 1935,” Turysta w Polsce, no. 5 (1936): 10.

${ }^{77}$ Ibidem.

${ }^{78}$ Ibidem.

${ }^{79}$ Władysław Krygowski, "Gorgany - góry czaru:” 8.

${ }^{80}$ Vide David Lowenthal, The Past is a Foreign Country (Cambridge: Cambridge University Press, 1985). 
"invented tradition," as understood by Eric Hobsbawm. ${ }^{81}$ It responded to a novel situation of interwar Poland in the form of reference to an old situation or, more precisely, in the establishment of a desirable past by quasi-obligatory repetition. Finally, the third device surfaced in the concept of the Main Carpathian Trail as a symbolic power, the phenomenon first defined by Pierre Bourdieu. ${ }^{82}$ The latter means exerting such symbolic pressure on the mountain borderland that corroborates Polish sovereignty in the region by means of a widely understood discourse. However, regardless of differences, all three devices had a common denominator: they effectively inscribed the Carpathians, especially the Lemko, Boyko, and Hutsul territory, into the cognitive framework of Polishness. In other words, they imposed such meanings on the mountains that strongly identified them with Poland and turned state assimilation of the highlanders, especially the Hutsuls, in the direction of national assimilation.

\section{Touristification of the Mountains}

An important concern and challenge for the interwar Polish elites constituted the elicitation of tourist traffic in the Central and Eastern Carpathians. This issue was closely connected with all three phenomena above, the exoticization of the mountains, and both soft and hard state-building in the region.

As I mentioned above, the presentation of Carpathians as an exotic attraction in the domestic space of the Second Polish Republic was to lure Polish tourists to the south-eastern corner of the country. Ossendowski tried hard to transfer his fascination for the mountains' exoticism to readers, so he expressed it overtly. He emphasized the need for turning the mass movement of tourists toward the Carpathians, especially the Central Carpathians, because it was the most impoverished highland with precarious links to Poland. According to Ossendowski's opinion, the irresistible charm of wild nature and its spa qualities transform the Lemko and Boyko regions into "an important outpost of state and private entrepreneurship, which must bring profits if only there happened indispensable investments, roads, hotels, sanatoriums, sports facilities, medical, and bathing centers etc." ${ }^{" 83}$ Ossendowski foresees profits: a "wave of people searching for health for the body and the soul, who would populate the Subcarpathia in the summer and winter season" enrich local population and, consequently, "its return to old trust and friendship for the only heir of this

${ }^{81}$ Vide Eric Hobsbawm, "Introduction: Inventing Traditions," in The Invention of Tradition, eds. Eric Hobsbawm and Terence Ranger (Cambridge: Cambridge University Press, 1983), 1-14.

${ }^{82}$ Vide Pierre Bourdieu, Distinction: A Social Critique of the Judgement of Taste, trans. Richard Nice (Cambridge: Harvard University Press, 1984).

${ }^{83}$ Antoni F. Ossendowski, Karpaty i Podkarpacie, 200. 
land - Poland." 84 Therefore, Ossendowski clearly applies national importance to touristic development of the Lemko and Boyko area, as it was to reinforce the Polish influences in the mountains due to the influx of Polish lowlanders and fostering of Polish affiliation of the highlanders.

As I also mentioned above, the soft and hard state-building projects in the mountain province had an inseparable touristic dimension, because they aimed at merging the province and its population with the center of the state and the rest of the Polish society. A lot of efforts were always put into making the programs of Mountain Holidays, Highland Congresses, and competitions in the uplands as attractive as possible. However, it was not all that was to draw visitors to the Carpathians. An organization that especially contributed to the increase of tourist traffic during the aforementioned shows was the League of Support for Tourism (Liga Popierania Turystyki), founded in 1935 by the Minister of Communication, Michał Budkiewicz. Since the League had large state funds for the development of mass tourism, it could offer considerable discounts to the visitors of mountain events. For instance, in 1936, before the March along the Hutsul Route of the Second Legionnaire Brigade, the League distributed "participation cards" at a low price, which entitled to a fifty percent discount on the train trip to Worochta, free return trip to the place of residence, free entrance to the finish line of the March, and accompanying events. ${ }^{85}$ Before the Mountain Holidays of 1935 and 1937, the League offered similar "cards" that entitled to a thirty-three percent discount for a train trip to Zakopane and Wisła and free return trip. ${ }^{86}$ Clearly, such conditions of participation in mountain events were very appealing, especially for less wealthy Poles like the Polish workers, the main target of the League.

Except for the periods of the biggest mountain events, the Polish authorities along with tourist and local lore organizations sought to intensify the influx of tourists to the mountains, especially in winter- and summertime. A widely-advertised annual project that aroused the interest of skiers from all over Poland (and abroad) was the Railway-Ski Rally, organized since 1932 by the Society for Promoting Skiing (Towarzystwo Krzewienia Narciarstwa) with the support of the Ministry of Communication. The Rally lasted ten days and nights. Its participants started in Cracow, then moved across the Polish Carpathians, from Jaremcze in Chornohora to Wisła in the Silesian Beskids, to finally return to Cracow. During the day, they skied in various ski resorts and, during the night, they had fun in the cars of an exclusive train, equipped with luxury restaurants, bedrooms, and bathrooms, and commonly referred to as the "Skiing-Dancing-Bridge." Although the Rally had an entertaining character, it also met some propagandistic

\footnotetext{
${ }^{84}$ Ibidem.

${ }^{85}$ Az, "Marsz Szlakiem II Brygady Legjonów:" 6.

86 “'Tydzień Gór’ w Wiśle:” 3.
} 
goals of the Second Polish Republic: as a journalist from the monthly Turysta $w$ Polsce puts it, the Rally promoted skiing together with "the beauty of our country," ${ }^{87}$ that is, the country of Poles, which seamlessly joined Lesser Poland with Cracow (the historic center of Polishness), Silesia and the Hutsul region.

While the Rally was dedicated to well-off skiers - it cost 200 zlotys per person (now approximately 500 euro) ${ }^{88}$ - there also was a broad and interesting tourist offer prepared for the less demanding and less wealthy visitors to the mountains. For instance, the League of Support for Tourism organized low-budget winter holidays in Worochta and the surrounding Hutsul villages. "Participation cards" sold by the League via, among others, the Orbis Travel Agency included a thirty-three percent discount for a train trip to Chornohora, a free return trip to the place of residence, a lump sum for stay in a guesthouse of third category with full board, a trip from Worochta to the village Foreszczenka by a narrow-gauge railway train, and a ski trip with an instructor. ${ }^{89}$ Except for paying a small fee, the only condition for obtaining the "card" for such an attractive holiday, was a minimum three-night stay in Chornohora. The League was interested in maximum tourist revival of the region. Thus, it tried to prevent very short, especially one-day, stays and strongly encouraged visitors to enjoy the mountains as long as possible.

All those projects would have misfired if there was no appropriate mountain infrastructure. In the 1920s, the shortage of such infrastructure still disturbed the development of tourism in the Eastern and Central Carpathians. However, during the course of the next decade, state, tourist and local lore institutions considerably improved the situation, especially in Bieszczady, Gorgany, and Chornohora. They built a new railway and narrow-gauge railway lines allowed tourists access to remote Boyko and Hutsul villages; new mountain trails paved the way to the most impenetrable and breathtaking viewpoints; new mountain shelters, hostels, and hotels provided accommodation for newcomers ranging from lower to upper social class. As a deficiency of lodgings was especially believed to deter lowland (particularly the affluent) vacationists from visiting the mountains, commentators of tourist life in the Second Polish Republic considered the latter achievement to be notably significant. For instance, the journalist Jim Poker admits that revenues brought to mountain enterprises by the "lucrative tourists" greatly surpass those brought by one-day "tourists-sportsmen." 90 This is why he highly praises the creation of a new hotel of the League of Support for Tourism in Sławsko, Eastern Bieszczady, finished in December 1936. According to Poker, the comfortable hotel will draw "lucrative" Polish visitors

\footnotetext{
${ }^{87}$ Adam Zieliński, "Rajd jedzie...," Turysta w Polsce, no. 2 (1935): 12.

${ }^{88}$ Maja Łozińska, Jan Łoziński, W kurortach przedwojennej Polski. Narty - Dancing - Brydż (Warszawa: Wydawnictwo Naukowe PWN, 2010), 9.

89 “Zimowe wczasy na Huculszczyźnie," Turysta w Polsce, no. 2 (1938): 15.

${ }^{90}$ Jim Poker, "Cepry i turystyka:” 10.
} 
to the mountains while their spending in local villages will strengthen highlanders' friendly attitude toward Poles and Poland.

Due to the aforementioned projects and investments, tourist traffic in the Central and Eastern Carpathians undoubtedly increased in the interwar period. The journalist Adam Zieliński seemed to be right when he writes in Turysta $w$ Polsce (1936) that, currently, "a trip to these mountains does not pose much more difficulty than that to the best-organized areas of the Western Beskids." 91 He does not neglect the fact that the influx of tourists to the south-eastern corner of Poland resulted from deliberate actions by tourist organizations with the large support of the Polish authorities. Zieliński also admits that this influx "fulfilled a serious state mission." What was the mission? The mission was to constantly stimulate state assimilation of the highlanders, which he only alludes, and the popularization of the Central and Eastern Carpathians among Poles, which he expresses openly: "Today the notion of Pop Iwan or Tarkuł is as clear for skiers as the notion of Hala Gąsienicowa or Babia Góra." 92 Despite the present tense used in the sentence, it presents a goal rather than an accomplished action. ${ }^{93}$ However, the juxtaposition of Pop Iwan and Tarkut, two Chornohora peaks, with the extremely popular spots in the Tatras (Hala Gąsienicowa) and the Żywiec Beskids (Babia Góra) was meaningful enough to suggest that the state mission in the Central and Eastern Carpathians was very advanced.

\section{Conclusions}

The tourist and local lore discourse in the Second Polish Republic changed the face of the Central and Eastern Carpathians, symbolically and literally. The exoticization of the mountains' localism, the development of regionalism, and the realization of many regionalism-inspired projects, from the Mountain

\footnotetext{
${ }^{91}$ Adam Zieliński, "Nowe możliwości turystyczne na Huculszczyźnie,” Turysta w Polsce, no. 1-2 (1936): 11.

${ }^{92}$ Ibidem.

${ }^{93}$ In the late 1930s, the "holiday and touristic action" in the Central and Eastern Carpathians was still regarded as needed or even "underestimated," as stated the letter by the Lviv Voivodship Office that informs about the establishment of a new touristic organization "Bieszczady," vide Derzhavnyj Arkhiv Lvivskoi Oblasti (DALO), found (f.) 2, opis (op.) 26, sprava (spr.) 198, p. 10. The "Bieszczady" Vacation and Tourist Association of Poviats and Municipalities of the Lviv Voivodship (Związek Letniskowo-Turystyczny "Bieszczady" Powiatów i Gmin Województwa Lwowskiego) was set up in 1938 (vide its status, DALO, f. 2, op. 26, spr. 198, p. 1-9) and it supported the activities of two already existing organizations, the Intermunicipal Association of Resorts and Spas of Stanisławów Voivodship "Eastern Carpathians" (Międzykomunalny Związek Letnisk i Uzdrowisk Województwa Stanisławowskiego "Karpaty Wschodnie") and the Summer Commission of Poviats and Municipalities of the Ternopil Voivodship (Komisja Letniskowa Powiatów i Gmin Województwa Tarnopolskiego), vide DALO, f. 2, op. 26, spr. 198, p. 17.
} 
Holiday to the Main Carpathian Trail, not to mention the intensification of tourist traffic in the Carpathians - all these phenomena initially appear as manifestations of a tendency to promote the diversity of the mountain borderland of interwar Poland. However, their overt or covert state-building made the discourse under investigation more complex and ambiguous. This very aspect transforms the simple focus on the Central and Eastern Carpathians into a strongly ideologized pursuit of modeling them into a Polish domestic landscape.

As reads the subtitle of Mythical Landscapes Then and Now. The Mystification of Landscapes in Search for National Identity, we may say that the real geographical landscape of the Central and Eastern Carpathians was "mystified," that is, covered with meanings that made it cognitive or imagined. ${ }^{94}$ Precisely speaking, the disposers of the tourist and local lore discourse - the Polish elites - imbued the Carpathians with ideological meanings of "ourness" which suggested that "we," Poles, were always there, marking the mountains with monuments of "old" glory and present domination. Consequently, the Lemko, Boyko, and Hutsul regions became appropriated by the Polish state and nation or, in other words, they were made into an imagined landscape, which I call domestic. Unlike the "national landscape" of the Tatras, the domestic landscape of the Central and Eastern Carpathians was not a geographical-cognitive space, with which Polish national identification solidified the most effectively. As I emphasized, the reason for such state of affairs was that before the First World War the Carpathians were less "discovered" than the Tatras and they were inhabited by ethnic groups dissimilar to Poles.

However, the domestic landscape of the Central and Eastern Carpathians was a geographical-cognitive space which, during the course of the interwar period, started appearing as securely tethered to Poland and integrated with a properly run modern state. According to the ideology that converted the Carpathians into a domestic landscape, links between this mountain periphery and the center of Poland had a bilateral character. On the one hand, the Lemkos, Boykos, and Hutsuls were supported by the Polish authorities and institutions to become loyal Polish citizens. On the other hand, Polish lowlanders were to become captivated by the south-eastern borderland of Poland. Hence the crux of the analyzed ideology: in the eyes of both groups the mountains turned into an indigenous part of the Second Polish Republic, regardless of their local and ethnic peculiarity.

Such an ideologization of the region was very effective and brought measurable results. The Lemkos, Boykos, and Hutsuls saw that it was no one else but the Poles who developed their territory after the First World War. Although many highland circles sympathized with political options other than the Polish regime, most frequently with Ukrainians, the highlanders mostly partook in Polish

\footnotetext{
94 "Preface," in Mythical Landscapes Then and Now, 5.
} 
mountain events willingly. Moreover, the highlanders undoubtedly profited from the increase of tourist traffic in the region. In turn, Polish lowlanders increasingly eagerly traveled to the south-eastern periphery of the state. It found its significant testimony in the fact that, in 1937, the monthly Turysta $w$ Polsce lists the Hutsul region among the most attractive and most visited areas of Poland, next to the Baltic coast, the Silesian Beskids, and the Tatra Mountains. ${ }^{95}$ The Central and Eastern Carpathians became replete with visible signs of Polish concern about the region and, simultaneously, of Polish rule over it, from the shortest mountain trails to the Marshal Piłsudski Main Carpathian Trail, from the smallest mountain shelter to the great hotel of the League of Support for Tourism in Sławsko. All these signs made the Carpathians into a familiar place for Poles, a conspicuous position on their mental maps.

One of the most significant, and last, signs of this kind was the location of the Polish Astronomical and Meteorological Observatory on the peak of Pop Iwan in Chornohora. The total cost of the undertaking exceeded one million zlotys (now two and a half million euro) while the initiative was supported by the Ministry of Military Affairs and honored by Marshal Piłsudski's name; thus, it constituted a strong symbol of Polish knowledge of - and power over - the Eastern Carpathians. The plans for the extension of the National Park of Chornohora, ${ }^{96}$ prepared in the late 1930s, confirmed that the Polish elites did not relinquish the project of the mountains' transformation into a domestic landscape even in the face of the Second World War. Had the war not interfered, the project would have surely continued. Although history developed in a different direction, we cannot exclude the possibility that the domestic landscape of the Central and Eastern Carpathians would have finally transformed into another Polish "national landscape."

\section{References}

Anderson, Benedict. Imagined Communities: Reflections on the Origin and Spread of Nationalism. London: Verso, 1991.

Bourdieu, Pierre. Distinction: A Social Critique of the Judgement of Taste, trans. Richard Nice. Cambridge: Harvard University Press, 1984.

Brocki, Eugeniusz. "Opryszki w Karpatach. Powieść z podań gminnych.” Hałyczanin, ed. Walenty Chłędowski. Lwów, vol. 2 (1830).

Crowley, David. "Finding Poland in the Margins: The Case of the Zakopane Style." Journal of Design History, vol. 14, no. 2 (2001): 105-116.

95 "Tani urlop jesienią," Turysta w Polsce, no. 9 (1937): 4-5.

${ }^{96}$ The Nature Reserve of Chornohora, of limited area, was set up in 1932 but it was to be transformed into a national park and considerably extended, vide Józef Kostyrko, "Czarnohorski Park Narodowy," Wierchy, vol. 11 (1933): 131-146. 
Dabrowski, Patrice M. "'Discovering' the Borderlands: The Case of the Eastern Carpathians." Slavic Review, vol. 64, no. 2 (2005): 380-402.

Dabrowski, Patrice M. "Borderland Encounters in the Carpathian Mountains and Their Impact on Identity Formation." In Shatterzone of Empires Coexistence and Violence in the German, Habsburg, Russian, and Ottoman Borderlands, eds. Omer Bartov and Eric D. Weitz. Bloomington-Indianapolis: Indiana University Press, 2013, 193-208.

Dabrowski, Patrice M. "Constructing a Polish Landscape: The Example of the Carpathian Frontier.” Austrian History Yearbook, vol. 39 (2008): 45-65.

Derzhavnyj Arkhiv Lvivskoi Oblasti (DALO), found (f.) 2, opis (op.) 26, sprava (spr.) 198.

Gąsiorowski, Henryk. Przewodnik po Beskidach Wschodnich, vol. 1, part 1: Bieszczady. Warszawa: Książnica-Atlas, 1935.

Gąsiorowski, Henryk. Przewodnik po Beskidach Wschodnich, vol. 1, part 2: Gorgany. Warszawa: Książnica-Atlas, 1935.

Gąsiorowski, Henryk. Przewodnik po Beskidach Wschodnich, vol. 2: Czarnohora. Warszawa: Książnica-Atlas, [1933].

Hobsbawm, Eric. "Introduction: Inventing Traditions." In The Invention of Tradition, eds. Eric Hobsbawm and Terence Ranger. Cambridge: Cambridge University Press, 1983, 1-14.

Horoszkiewicz, Roman. Szlachta zaściankowa na ziemiach wschodnich. Warszawa-Pińsk: Polskie Towarzystwo Turystyczno-Krajoznawcze. Oddział Piński, 1936.

Huculskim szlakiem II Brygady Legjonów Polskich. Warszawa: Wyd. Tow. Przyjaciół Huculszczyzny, 1934.

Jastrzębski, Stanisław. Kim jesteśmy? O szlachcie zagrodowej w Małopolsce Wschodniej. Przemyśl: "Pobudki," 1939.

Kozłowski, Maciej. Między Sanem a Zbruczem. Walki o Lwów i Galicję Wschodnia 1918-1919. Kraków: Wydawnictwo Znak, 1990.

Krótki przewodnik po Huculszczyźnie od Hnitesy po Rogoze, ed. komitet redakcyjny. Warszawa: Główna Księgarnia Wojskowa, 1933.

Lowenthal, David. The Past is a Foreign Country. Cambridge: Cambridge University Press, 1985.

Łemkowie - zapomniani Polacy. Województwo krakowskie, Łemkowszczyzna zachodnia: materiaty onomastyczne, ed. Aleksander Bartoszuk. Warszawa: Sekcja Naukowa Komitetu do Spraw Szlachty Zagrodowej na Wschodzie Polski, 1939.

Łozińska, Maja, et Jan Łoziński. W kurortach przedwojennej Polski. Narty - Dancing - Brydż. Warszawa: Wydawnictwo Naukowe PWN, 2010.

Madajczyk, Czesław. "Dokumenty w sprawie polityki narodowościowej władz polskich po przewrocie majowym.” Dzieje Najnowsze, no. 3 (1972): 137-169.

Magocsi, Paul R. Shaping of a National Identity: Subcarpathian Rus', 1848-1948. Harvard: Harvard University Press, 1978.

Magocsi, Paul R. The People From Nowhere: An Illustrated History of Carpatho-Rusyns. Uzhorod: V. Padiak Publishers, 2006.

Moklak, Jarosław. The Lemko Region in the Second Polish Republic: Political and Interdenominational Issues 1918-1939, trans. Timothy Williams. Kraków: Jagiellonian University Press, 2013. 
Mythical Landscapes Then and Now: The Mystification of Landscapes in Search for National Identity, eds. Ruth Büttner, Judith Peltz. Yerevan: Antares, 2006.

Ossendowski, Antoni Ferdynand. Beasts, Men and Gods. New York: E. P. Dutton \& Company, 1922.

Ossendowski, Antoni Ferdynand. Huculszczyzna. Gorgany i Czarnohora. Poznań: Wydawnictwo Polskie R. Wegner, [1936].

Ossendowski, Antoni Ferdynand. Karpaty i Podkarpacie. Poznań: Wydawnictwo Polskie R. Wegnera, [1939].

Paruch, Waldemar. "Mniejszości narodowe w myśli politycznej obozu piłsudczykowskiego (1935-1939)." In Polityka narodowościowa państw Europy Środkowowschodniej, eds. Jacek Ziemowit Pietraś, Andrzej Czarnocki. Lublin: IEŚ-W, 1993, 86-102.

Pawłowski, Stanisław. "Regionalizm geograficzny i jego rozwój w Polsce.” In Ruch regionalistyczny w Europie, vol. 2, ed. Aleksander Patkowski. Warszawa: Sekcja Regjonalistyczno-Krajoznawcza Związku Nauczycielstwa Polskiego, 1934, 3-20.

Pulnarowicz, Władysław. Rycerstwo polskie Podkarpacia (dawne dzieje i obecne obowiazki szlachty zagrodowej na Podkarpaciu). Przemyśl: "Pobudki," 1937.

Reinfuss, Roman. "Etnograficzne granice Łemkowszczyzny." Ziemia, vol. 26, no. 10/11 (1936): 240-254.

Reinfuss, Roman. “Łemkowie (opis etnograficzny).” Wierchy, vol. 14 (1936): 1-24.

Reinfuss, Roman. "W sprawie granicy łemkowsko-boykowskiej.” Kurier Literacko-Naukowy, no. 7, appendix to Ilustrowany Kurier Codzienny, no. 48 (17 February 1936): XIV-XV.

Reinfuss, Roman. "Wschodnia granica Łemkowszczyzny.” Kurier Literacko-Naukowy, no. 28, appendix to Ilustrowany Kurier Codzienny, no. 193 (13 July 1936): IX-X.

Reinfuss, Roman. "Ze studiów nad kulturą materialną Bojków.” Rocznik Ziem Górskich. Warszawa: Zakłady Drukarskie W. Piekarniaka, 1939: 238-279.

Reinfuss, Roman. Fotografie. Karpacki świat Bojków i Łemków, eds. Zbigniew Libera, Hubert Ossadnik. Olszanica: Wydawnictwo Bosz and Muzeum Budownictwa Ludowego w Sanoku, 2016.

Statut Towarzystwa Przyjaciół Huculszczyzny. Warszawa: Towarzystwo Przyjaciół Huculszczyzny, 1934.

Sulimirski, Tadeusz. "Trakowie w Północnych Karpatach i problem pochodzenia Wołochów." Acta Archeologica Carpathica, vol. 14 (1974): 79-105.

The Lemkos of Poland, eds. Paul J. Best, Jarosław Moklak. Kraków-New Haven: Carpatho-Slavic Studies Group, 2000.

Turysta w Polsce, no. 1-12 (1935-1938).

Wielocha, Andrzej. Przedwojenne Bieszczady, Gorgany i Czarnohora. Najpiękniejsze fotografie. Warszawa: Wydawnictwo RM, 2013.

Wierchy, vol. 1-16 (1923-1938).

Województwo stanistawowskie i tarnopolskie. Rzeszów: Libra PL, 2012.

Województwo stanisławowskie i tarnopolskie. Warszawa: Wydawnictwo Tadeusza Złotnickiego, 1930.

Wöller, Burkhard. "Misja 'cywilizacyjna' czy 'okupacyjna'? Aneksja Rusi Czerwonej w czasach Kazimierza III w kolonialistycznym dyskursie polskich i rusińskich historyków w habsburskiej Galicji." Historyka, vol. 42 (2012): 133-145. 